Анђелка Митровић

Катедра за оријенталистику

Филолошки факултет

Универзитета у Београду

andjelkam@fil.bg.ac.rs

https://doi.org/10.18485/ai_gozik.2019.ch11

821.411.21.09-1

\title{
ВИНО У ОРИЈЕНТАЛНОЈ ПОЕЗИЈИ
}

Вино и здравице нису присутни у свим оријенталним поетским традицијама у истом обиму и на исти начин. У овом раду, бавићемо се вином у арапској поезији, код песника: Бешара Ибн Бурда (VIII) и Абу Нуваса (VII-VIII), који су допринели истинској модернизацији арапске поезије. Њихов утицај је био веома далекосежан и протеже се и до великана персијске, али и светске лирике, какви су Хајам (XI-XII) и Хафиз (XIV). Њихова поезија, особито кад је реч о точењу и испијању вина, што исламска вера забрањује, дозвољава двоструко тумачење - буквално и реално, односно пренесено и алегоријско, мистично.

Кључне речи: Арапска поезија, персијска поезија, вино, тумачење поезије, Абу Нувас, Омер Хајам, Хафиз.

У књизи невеликог обима насловљеној Филозофија вина Бела Хамваш каже да вино има „божанско лице“ и да сва вина спадају под „једно једино божанство“ (2011: 29). То пиће „са божанским лицем“ само одабранима и посебно надаренима пружало је и пружа двоструко задовољство - они једно осете док га пију, друго, пишући о њему. 
Велика су књижевна имена ушла у легенду по пијанчењу; та је легенда постала неодвојива од њихова дела. Напијало се у свим епохама и ваљда још од прве писане речи. Писци су цугали из гушта или позе, ради окрепе душе, у славу боеме, следећи књижевну традицију пића, опонашајући једни друге, из очаја или зависности, лечећи љубавне јаде или какве друге бољке, из бунта и страха од смрти, у бегу од самоће или у јаду емиграције. Цугало се из ко зна којих све разлога, мистичних, душевних, самоубилачких, породичних, сексуалних. [...]

Цела је историја књижевности једна бескрајна точионица. Точило се онде пића и духа, а да се то двоје није узајамно потирало. Дакле, у тој пивници локало се и лочући сатирало до „растројства свих чула“ како је Артур Рембо најрадије дефинисао песништво. (Ковач 2001)

На Истоку се није баш толико цугало као на Западу, па вино није, у толикој количини присутно у оријенталним књижевностима. Но, вино, заправо, никада није престајало да се точи на Блиском истоку и увек је било винопија и винске поезије у којој је опевана његова сласт. Вино и здравице јављају се још у књижевности древних блискоисточних народа, на пример, срећемо их у староегипатској књижевности из доба Новог царства (1600-1100; 18-20 династије). Но, арапска, персијска и друге поетске традиције, које припадају исламском цивилизацијском кругу, баш и нису толико обливене вином. Куранска забрана конзумирања алкохолних пића, јасно изречена у више ајета, свакако је допринела томе. Због ауторитета који су представљали, Куран и званични хадиси играли су велику улогу у формирању исламских стандарда моралног понашања. „Пророк Мухамед је био сасвим јасан: 'Бог је проклео вино и сваког који га пије, који га сипа, који га продаје, који га цеди, и оног за кога се цеди, и ко га превози, и за кога се превози, и ко ужива у новцима зарађеним од 
вина'. Мухамед је забранио [...] најгоре од свега, оног ко пева о вину“ (Pivo 2017: 119). И поред свега тога, бројни муслимански песници славили су и опевали вино и пијанство (Šamić 2014: 92).

Арапска поезија је, свакако, најаутентичнија и најпопуларнија уметност међу Арапима. Настајала је међу бедуинима номадима који су крстарили пустињама и степама Арабљанског полуострва, као и међу седелачким племенима и братствима настањеним око оаза и у градовима. Сва та племена, и номадска и седелачка, имала су особену друштвену и верску организацију, а бавила су се сточарством, земљорадњом, занатством и трговином. Најзначајнији град била је Мека, истовремено и трговачки и верски и културни центар за све преисламске Арапе. Колико је место настанка арапске поезије потпуно евидентно, толико су њени почеци и развој обавијени маглом, а аутентичност под знаком питања и на Истоку и на Западу.

Веома је несигурно датирање ове поезије на основу онога што је из ње преживело. Извесно је да се на основу испитивања мајсторских примерака намеће закључак да су већ и они плод дуге претходне еволуције. Постоји такође свакако дуг временски период између настанка ове поезије и њеног бележења. Ово оригинално песништво по многим својим обележјима је бедуинско. Преносили су га усмено, с генерације на генерацију, рецитатори (ар. rāwi), који су често и сами били ствараоци. (Đukanović 1982: 102)

У сваком случају, почеци арапске поезије „скривени су у непрозирној тами историје Арабљанског полуострва, да би на стотинак година пре појаве ислама бљеснули у готово савршеној, високо уметничкој форми, као један од најаутентичнијих друштвених и културних чи- 
нилаца у племенској заједници Арављана“ (Tanasković 1977: 129). У арапској поезији из преисламског периода (ap. ğāhiliyya) доминира свеобухватна слика живота бедуинских племена. Она носи дубок печат аутентичног арапског духа и схватања. У њој налазимо доста података о племенском уређењу и хијерархији унутар племена, о ратовањима и примирјима, караванској трговини, караванским путевима око Арабије, лутањима кроз пустињу од једног до другог станишта... „Но, у њој налазимо и обавјештења о 'унутрашњој слици' живота, о томе како су стари Арапи мислили, како су се односили према животу, према вјечном питању о смислу постојања, како су осјећали... [...] Дакле, налазимо у њој оне општељудске теме које су увијек присутне у свакој правој поезији и умјетности уопште, налазимо човјека, налазимо себе“ (Grozdanić 1971: 10-11).

О месту поезије међу бедуинским Арапима најбоље сведочи статус песника у њиховим племенским заједницама. Песник је заузимао истакнуто место у племенској хијерархији и стајао одмах уз вођу и врача. Био је гласноговорник свог племена, у својим стиховима описивао је њихова друштвена, етичка и мисаона стања и изражавао колективна осећања, мисли, тежње... На песников менталитет и схватања утицао је пре свега крајолик у коме је живео и певао, а у том крајолику преовладавају једноличне боје пустиње. Међутим, бедуински песник је и у том мору песка налазио пејзаже пуне лепоте и живота и топлих боја.

Песничка остварења преисламског периода, која су сачувана до наших дана, сведоче да су Арапи неговали поезију и да је улога песника у овој раној арапској заједници била сасвим изузетна. Песник бедуин имао је задатак да слави своје племе, да обесмрти његове подвиге у биткама у којима и сам учествује, а исто тако да упути оштре 
погрде непријатељском племену. Да би успео, песник је морао да буде уметник и да остане разумљив. Резултат је био да се створила песничка професија, а професионализам је водио стереотипности и артизму. (Đukanović 1982: 102)

Основна форма ове поезије јесте моноримична песма од педесет до сто стихова, касида (ap. qaÒĐda) „песма с циљем“. Она је састављена од неколико тематских целина, међу којима „не постоји чвршћа органска и смисаона повезаност. Једина веза јесте „мелодија, ритам и слик“ (Simić 1979: 855). Њена тематика строго је утврђена и везана за племенски живот и социо-културне прилике преисламских Арапа. Касида представља имагинарно песниково путовање до неког, такође, имагинарног одредишта. Циљ сваког песника био је, поред осталог, да изрази љубав својој вољеној, кроз љубавни елегични пролог и сећање на њу, кроз угасла љубавна огњишта. У касиди преовлађују описи природе, пре свега, пустиње и пустињског начина живота. Унутар тог дескриптивног слоја ређају се сталне и утврђене поетске слике, као што су упечатљиви описи пејзажа у којима су бедуини живели, посебно флоре и фауне појединих предела, пре свега, верне камиле, затим орла, антилопе, дивљег магарца, шакала, хијене, лава... Затим, ту је буђење пустиње, путовање по подневној жеги и ужареном песку, пустињска олуја која доноси кишу и нагле промене у пустињском растињу, описи воде, устајале посебно, пустињске оазе, пустињске ноћи која доноси свежину, неба препуног звезда, али и страшила, џинова и немани... „Ова поезија, реалистична у представама, сиромашна је у осећањима. Уводна тема, обично конвенционална, зове ce nasĐb; то је љубавни увод који садржи опис напуштеног боравишта, 
драге и носталгије изазване њеним одласком. И док се песник сећа својих састанака са вољеном, у стиховима које ниже описује природу, пустињу, животиње, сцене из лова, олују и слично“ (Đukanović 1982: 103).

Строго утврђени и окоштали поетски комплекс касиде постао је и остао песнички канон арапске поезије, који су готово сви каснији песници опонашали, чврсто се држећи језичких и естетских стандарда, утврђених конвенција, дескрипције, ритма, вокабулара... не додајући томе суштински ништа ново. Арапски песник се „дисциплинујући сопствено надахнуће, [...] трудио да у што већој мери овлада узвишеним занатом уметничког исказивања, на основу канонских дела мајстора, свестан да је идеалан склад ван његових људских домашаја. [...] Уношењем дашка инспирације своје стваралачке личности, арапски класични песник скромно обогаћује ризницу једне велике традиције, за коју зна да је изнад њега, али и да му припада“" (Tanasković 1977: 103).

Сурови пустињски услови живота, у којима је настајала арапска поезија нису баш били погодни за конзумирање алкохола. У ограниченом караванском пртљагу натовареном на „пустињске лађе “ мешине са водом су биле најважнији део, али би се ту нашла и понека мешина с вином. У плејади великана преисламског периода неколицина њих је певала, поред осталог и о вину. Ел Аша (Maymūn Ibn Qays al-'Ašā'; †625?) jeдан је од најугледнијих преисламских песника, који је много путовао и на многим дворовима се обрео. Путовања по Оману, Сирији, Палестини, Месопотамији, Неџрану и Хадрамауту проширила су његове видике и обогатила га многим знањима што се, по природи ствари, одразило и на његову поезију. У његовом дивану преовлађују панегирици, али је опевао и „слатко и ми- 
ришљаво вино, испијано у крчмама уз звуке персијске лауте“ (Gabrijeli 1985: 50).

Међу преисламским песницима било је и Јевреја и хришћана. Најпознатији хришћанин међу њима је Ел Ашин савременик Ади Ибн Зејд ('Adi Ibn Zayd; 550-600), који такође спада међу прваке преисламске поезије и који је у историји арапске књижевности помињан као први изразити вински песник. Значајан податак у његовој биографији јесте и то да је био један од првих писмених људи свог времена. Боравио је на лахмидском двору у ал-Хири, али и на оном Краља Краљева у Ктесифону. Добро познавање персијског језика и персијске културе обликовало је његов песнички израз у смислу напуштања бедуинских канона и архаичности и увођења нових тема, као што су „дионизијске песме, чији аутономни развој, изван склопа касиде, изгледа управо с њим и започиње“ (Gabrijeli 1985: 52). Из тог дела његовог опуса издвајамо неколико дистиха из Винске песме.

Једног дана јутарну чашу пожелеше / лепа робиюа дође у десној руии ибрик се ғиите

Наточи она вино кад оно ко из ока сок / оцеђено бистро вино, прави самоток

Кад га чистог пијеш - горко, скупља уста / а са водом слатко бива - као жела пуста

Поврх нега мехурићи као драги камен / ирвене се, од мућкана, правог вина знамен

Вода што му прија, вода из облака / не из баре, мутна од многих папака.

(Симић, прир. 1979: 30)

У последњу генерацију преисламских песника спада и Абу Михџана (’Abu Mî̂̂Ean; †638), прави песник „који је достојан помена по полетној спонтаности својих ди- 
онизијских песама“, а чије песничко умеће дочаравају следећи стихови.

Кад умрем, сахраните ме под виновом лозом, и корење њено нек натапа моје кости.

Не сахрањујте ме у пустињи, јер се бојим да после смрти нећу више моћи да га окусим.

Вино боје шафрана залиће мој гроб и заробиће ме пошто га дуго будем пио.

(Gabrijeli 1985: 83)

Професионални песници-луталице који припадају последњој генерацији преисламских песника такође су унели одређене промене у арапску поезију. Они су боравили и међу номадским и међу седелачким племенима, на дворовима и на сајмовима у Сирији, Месопотамији, Хадрамауту, Оману, Јерусалиму... Својим добрим познавањем народа са тих подручја и њихових обичаја умногоме су обогатили традиционалну пустињску поетику. Ови песници били су оштри сатиричари и добро плаћени панегиричари, а врло радо су певали и о вину.

Појава ислама унела је радикалне промене у све сегменте живота и друштвене организације преисламских Арапа, али не и у поезију. Стоји у Курану да Мухамед није волео песнике, али додатно објашњење каже да се то односи само на оне који нису прихватили његова откровења и нову веру. Шта више, био је веома наклоњен својим панегиричарима, међу којима су најпознатији Ибн Зухеир (K'ab Ibn Zuhayr; †662) и Хасан Ибн Сабит (ÍlassÁn Ibn Õábit; 563-674). После Мухамедове смрти (632), у време владавине његових наследника - четворице правоверних халифа, а потом и династије Омајада (661-750), муслиманска заједница - ума се учврстила и постала јака и стабилна држава, чије су се границе, великим освајањима, знатно прошириле. У време вла- 
давине Омајада, арапски коњаници заузели су и исламизовали Месопотамију, Персију и велики део средње Азије, а на западу су низали победе у Египту, Магребу и Андалузији. Брзина освајања принудила је Омајаде да изнађу и спроведу ефикасан систем управе. Омајадске халифе веровале су „да је ширење Ислама и раст њихове свјетовне власти једна те иста ствар; уосталом, не може се заборавити да се Ислам, управо за вријеме њихове владавине, а дјелом и на њихов потицај, појавио као свјетска религија“ (Smailagić 1990: 638). Време владавине ове чисто арапске династије представља „највећу афирмацију арапског народа и историје, и [...] његову највећу културну експанзију унутар оквира властитог етничког састава“" (Gabrijeli 1985: 86). Будући да су омајадске халифе гајиле склоност према свему што је арапско, бедуинска поезија била је посебно на цени (Đukanović 1982: 108). Омајадски двор у Дамаску постао је стециште песника, особито панегиричара, чија поезија прати и изражава сложене унутрашње односе и борбе различитих слојева и група у халифату. Многи неарапски народи који су се нашли у новим границама халифата унели су промене у арапско друштво и културу, а у тим, новим условима и арапска поезија, претрпела је одређене утицаје (Hiti 1983: 228; Gibb 1974: 32-45; Nicholson 1969: 181-254). И поред тога што у овом периоду преовладава пуко имитирање преисламске поезије, јављају се и нове врсте, пре свега, љубавне поезије, које цветају особито у Хиџазу. Из појединих делова касиде, „који имају готово жанровске карактеристике и самосвојност“ развили су се касније нови и самостални поетски жанрови у арапској поезији (Tanasković 1977: 132). Део песника, који су установили култ трагичних бедуинских љубавника и страдалника, који оплакују своју несрећну и недостижну љубав и исказују свој 
бол и патњу за вољеном, потицали су из различитих бедуинских племена. Насупрот њима, у Меки и Мадини, се, из љубавног прелудија касиде, а под утицајем персијских пјесника, развила градска арапска лирика, сасвим другачијег типа, чулна и раскалашна. Њен процват везан је за отварање многобројних клубова и салона, у којима се уживало и забављало, уз музику, песму и игру, што је тој средини давало „чисто хедонистичка обележја“" (Simić 1979: 895). Родоначелник и највећи песник градског газела је Омар Ибн Аби Рабиа ('Umar Ibn Abi RabĐ'a; 644-719), мајстор еротске поезије, „мекански Дон Жуан“, богати и безбожни припадник племена Курејш, „чији је главни посао био изјављивање љубави лијепим женама" (Hiti 1983: 237). Он је у својим газелима славио љубавне подвиге, чулну љубав, страст, удварање..., једноставним језиком лишеним архаизама и чудесном природношћу. Његова поезија је огледало друштвеног живота богатих меканских слојева и галерија меканских лепотица са свим њиховим чарима и дражима, ћудима, очијукањима, љубоморама, сузама, сплеткама, свађама... (Gabrijeli 1985: 105-107). Стихови овог „Овидија Арабије“, рецитовали су се и певали по салонима и клубовима, стварали у њима посебну атмосферу и утицали на њихову врло значајну улогу у монденском, и литерарном животу Меке (Симић 1971). У свему томе било је, сигурно, и доста вина, мада се поезија Омара Ибн Аби Рабие не може сматрати винском.

Градски газел, врло разуђен у погледу садржаја, цветао је и у Сирији, односно Дамаску, посебно кроз дионизијску поезију, која је ту имала врло јаку традицију. Ступањем на власт, Омајади су настојали, пре свега, да модернизују државу у сваком погледу, а на плану културе, уметности и поезије обновили су покидане везе с богињама вина, пјевања и свирања. Они „из званичног 
дворског и великодостојничког живота и понашања елиминишу бедуински примитивизам и уводе манире и рскош византијског и персијског двора“. Омајади су званично успоставили институцију мецената, коју су подредили у потпуности „својим световним циљевима, користећи песнике као своје династичке трабанте“ (Симић 1979: 893, 894). Институт мецената какав су Омајади васпоставили, преузеле су касније и абасидске халифе, њихови везири и намесници дајући посебне привилегије својим панегиричарима, што не само да је панегирик учинило „нарочито популарним обликом поетских састава него је и пјеснике натјерало да понижавају своју умјетност, а резултат је био лажни сјај и празне бомбастичне фразе, за које се често говорило да су карактеристика арапске поезије“ (Hiti 1983: 369). Меценат је омајадски двор учинио стециштем песника и утицао на настанак политичко-сатиричко-панегиричке поезије, чији су главни представници били Ел Ферездек (al-Farazdaq; са 640-732), Џерир (Ğarīr Ibn 'AÔiyya; ca 653-728) и Ел Ахтал (Çiyyāt Ibn Çawt al-TaÈlibî al-AhÔal; са 640-710), сатиричари и панегиричари, који су својим стиховима славили омајадске халифе и бранили њихове интересе. Хришћанин Ел Ахтал, најталентованији међу њима, био је званични дворски панегиричар шестог халифе Абделмалика ('Abd al-Malik Ibn Marwān; 647-705; владао 685-705). Овај безбожни винопија писао је и љубавну и винску поезију у којој је опевао свој раскалашни и слободни живот (Gibb 1974: 42; Nicholson 1969: 239-242; Gabrijeli 1985: 95-99). Из Ахталовог опуса издвајамо неколико дистиха из песме Вино.

Као да сам био кад су хтели поћи / неко на све спреман, заведен у ноћи

Ко неко огрезо у вину, оно још ми држи главу / мада мли- 
тав сав у нечију пије ставу

Понекад га усправљају или вуку као врећу / никакве га друге мисли до о вину не салећу

Груди му се надимају кад наздрави ко за славу / а кад мало од нег сркне то помути већма главу

И ја пробах, кунем ван се ал'ме прими свом силином / кад караван натоварен палестинским добрим вином на коме су све мешине од преврнуте биле коже / пуне вина, с обе стране да с' усправно ићи може

Ја сам срео и викнуо: 'Вина мени дајте!' / а кад застадох рекох: „Штедро ми сипајте!“ (Симић прир. 1979: 35)

Уз Ел Ахтала још један занимљиви песник допринео је много развоју и популарности винске поезије. То је халифа Ел Валид Ибн Јазид (al-WalĐd Ibn YazĐd; убијен 741), који је оставио дубљи траг у поезији него као владар (владао свега годину дана). Његови пригодни стихови, у којима је опевао вино и теревенке, а које му је диктирало „шаљиво и епикурејско надахнуће, час цинично, час меланхолично, претежно с брзим, лепршавим римама, до тада мало коришћеним у званичној поезији“, наговештавају нову епоху и модернизам у арапској поезији и претеча су винским песмама хамријатима Абу Нуваса. И из његовог винског опуса издвајамо неколико стихова.

Какву дивну ноћ проведох у Деир Бавани, тамо где се точило вино и орила песма!

Кружила је чаша, и ми смо кружили у игри, а незналице мишъьаху да смо полудели.

Пређосмо код намирисаних жена, и песме и вина, и ту остадосмо.

И начинисмо од Божјег халифе Петра, а од дворског министра Јована.

Причестисмо се и ничиие падосмо пред крстовима у ниховом манастиру, попут неверника (Gabrijeli 1985: 107-108). 


\section{Пиће и забава}

Једног лепог дана / док сам слатко вино пио Из Русафе стиже гласник / о смрти ми глас донио Донесе ми писмо ево / да Хишама нема више И пружи ми печат ияарски / многа душа за н' уздише Ал ја имам другу бригу / вино пијем вино чисто Робиюа ми далье свира / на веселье ја сам присто. (Симић прир. 1979: 54)

Истинска модернизација арапске поезије, и у формалном и у тематском смислу, везује се за „златни век“ (са 750-850), односно за почетни период владавине династије Абасида (750-1258), када халифат добија космополитски карактер. Стварању нових културних образаца и вредности допринели су у великој мери представници покорених народа, особито Персијанци, који су дали Арапима „најбоље филологе, најслободније тумаче Кур'ана, најдубокоумније философе уопште, носиоце културних кретања. Сви су они писали важна дела на арапском језику, јер је то био императив оног времена... [...] Но, схватања и идеје ових научника били су персијски, слободоумни и еластични“ (Bajraktarević 2012: 32). На Персијанце су се халифе ослањале и у организацији административног апарата и судства, а страним плаћеницима, углавном Турцима, попуњавали су војску. Но, треба, свакако, истаћи чињеницу да Арапи нису само асимилирали персијску научну и литерарну традицију и класичну баштину Грчке, него су их и прилагодили својим специфичним потребама. Велики економски прогрес пратио је и процват културе и науке, нарочито теологије, права, астрономије, математике, медицине, филологије, па, наравно, и књижевности. Арапски језик, као језик владајуће религије, као језик природних наука и као књижевни израз имао је посебан значај у смислу остварења 
културног јединства халифата (Đlizarević 1979: 927, 929). Већ од половине 9. века почиње слабљење и дезинтеграција абасидског халифата, а у 10. веку стварна власт абасидских халифа не сеже много даље од Ирака. Међутим, иако провинције на северу Африке, у Персији и централној Азији учвршћују и шире своју аутономију и рапидно слабе политичку моћ.халифа, иако су знаци декаденције све израженији, Багдад је и даље морално средиште исламског света, у коме цветају култура и духовни живот и стварају највећи арапско-муслимански научници и књижевници (Gabrijeli 1985: 115-228; Gibb 1974: 51-108; Nicholson 1969: 285-365). Кад је реч о поезији, класична касида је и у абасидско доба била веома омиљена форма и међу арапским и међу персијским песницима, али процес разградње њених поетских оквира и настајање нових песничких врста из ње, започет у доба Омајада, интензивиран је, а један од исхода свега тога јесте и настанак абасидске модерне школе. Песници модернисти (ap. muÎdi×Ũn) су и даље поштовали неприкосновена правила везана за метар, стих и риму, али су се окретали сасвим новим темама: телесној љубави и вину и пијанству, али и аскези и мистици.

Ови 'модерни' осећају непримереност традиционалне пустињске поезије новом друштвеном и културном животу, извештаченост старе касиде, овешталост њених канонских тема, те свему томе, понекад изразито полемично, супротстављају своју нову уметност; кратке фрагменте изван сваке схеме, без језичких архаизама, који непосредно изражавају њихова искуства весељака и дворјана, какви су већином ови песници, али и душевне муке и религиозне сумње. То је поезија вина, љубави, сласти живљења у културној и префињеној средини; описи палата и дотераних перивоја уместо туробне пустиње, ловачких паса, петлова, риба из рибњака, уместо вечне камиле. (Gabrijeli 1985: 118) 
Један од зачетника модернизма и најстарији модерниста био је слепи песник Бешар Ибн Бурд (Baššār Ibn Burd; 714-784), чија је поезија „сва од овог света, од тела и страсти“ (Tanasković 1977: 134). У његовој поезији се налазе све одлике нове школе - нове фигуре, нове теме, нове идеје, „реализам без предрасуда, течан и разговетан језик, честа употреба дијалога, градска позадина (Gabrijeli 1985: 123). У његовој поезији мешају се мотиви песничког и политичког бунта, отворена наклоност према маздеизму, његовој првобитној вери, критика арапског менталитета... Предање га повезује с одређеним јеретичким, мутазилитским и манихејским круговима и каже да је оптужен за јерес и највероватније уморен батинама у некој мочвари (Gibb 1974: 61; Nicholson 1969: 373-374). Из његовог разноврсног и богатог поетског опуса, који обухвата конвенционалне касиде, панегирике, сатиричне песме, епиграме, љубавну и винску поезију, издвајамо песму „О вину“.

Чар младости и ускиптело вино у чашама

Обојише тьббавне легенде мојим ранама.

Ђубав и вино родише се са мном исте ноћи заједно са мном обоје ће и у гроб поћи.

Има туди што су од живота подигли руку, а ја око свог живота, чаше вина, стежем шаку.

За једно предвечерне сунще на свом заласку, жртвујем хиљаду јутарюих сунаца на изласку.

Берачу грожђа, дланови твоји румени и прсти на руци нека су увек благословени.

Свако ко зна истински пити

Чашу узбурканог вина неће опростити. (Tanasković prir. 1977: 37)

Велики допринос модернизацији арапске поезије дао је још један модерниста - Абу Нувас (al-Íasan Ibn 
Hāni’ al-Íakamî AbÙ Nwās - „Коврџави“; ca 756-814), један од истинских поетских великана и, по многима, најталентованији арапски песник. Из родног Ахваза у Ирану пут и жеља да усаврши арапски језик прво су га довели у једно бедуинско племе где се напајао чистим изворним арапским језиком и класичном арапском поезијом, а потом у Басру и Куфу, месопотамске градове у којима су деловале познате арапске граматичке школе (VIII-IX), где је открио многе тајне класичног арапског језика. После овог „језичког шегртовања“, путовао је по Царству, стигавши до Египта, да би се напокон скрасио у Багдаду, на двору славног Харуна ел Рашида (HārÙn al-Rašìd; 763-809; владао 786-809) и његовог сина Амина (al-'Amin; 787-813; владао 809-813). Ту је живео веселим и разузданим животом, који је врло верно опевао у својој поезији. Његово дружење и тумарања багдадским улицама и базарима са поменутим халифама описани су и у Хиљаду и једној ноћи, али стихови који му се у овом зборнику прича приписују, свакако нису аутентични (Gabrijeli 1985: 119-123; Gibb 1974; 62-62; Nicholson 1969: 292-296; Крачковский 1956: $336-$ 350). Овај самосвојни песник био је велики реформатор арапске поезије, који је, иако одгајан на класичној арапској песничкој традицији и касиди, врло брзо раскинуо са њом, одбацио њене шематске манире и стеге и увео непосредност и слободу израза, једноставан и јасан језик, као и нове теме и садржаје. По први пут у арапској поезији певао је о различитим врстама забаве, истинској љубави, радости и весељу, пићу, а та хедонистичка слободоумна лирика, не може се замислити без музике и песме, без вина - набиза (ap. nabīd), забрањеног рујног напитка, без чувеног вина од урми, вавилонског вина, вина благог, вина јаког, вина пенушавог, без пуних пехара и крчага, без крчмара (перс. sāki)... Диван, 
који у Европи још увек није доживео своје комплетно критичко издање, садржи око 500 аутентичних песама - касиде у старом стилу, описну и еротску лирику, песме о лову (ap. ÔardiyyÁt), урбане елегије (ap. marātî), дитирамбе и панегирике (ap. madî) у којим, као и сви његови претходници, ласка својим абасидским меценама и пријатељима, затим оштре и заједљиве сатиричне песме (ap. hiğ̄a), као и дионизијску поезију и винске газеле (ap. hamriyyÁt), у којима је остао ненадмашан. „Но у песмама о вину осећамо правог песника. Он је успео да на ову тему, коју је ранија традиција већ обилато обрадила, те сама по себи не представља ништа ново, створи читаву гаму варијација које су и данас класичне“. (Gabrijeli 1985: 121) Опевање вина често је код њега био протест против духовно-конзервативне средине, али и против идеала бедуинске арапске поезије. Више су му одговарали идеали веселог живота сасанидске Персије (Крачковский 1956: 336).

Он је стварно имао мало такмаца у љубавним осјећајима, еротском изразу и елегантној дикцији. Он је у муслиманском свијету par-exellance лирик и пјесник винских пјесама. Многе пјесме о љепоти дјечака, које се приписују овом раскалашном љубимцу абасидског двора, као и његове пјесме у славу вина (hamriyÁt), које нису престале да одушевљавају оне који читају и пију, бацају интересантно свијетло на савремени аристократски живот. Газели Абу Нуваса тј. кратке љубавне пјесме које садрже од пет од петнаест стихова, опонашају обрасце перзијских пјесника, који су ову врсту гајили много прије Арапа. (Hiti 1983: 367-368)

Ево неколико стихова који ће, бар донекле дочарати песничко умеће Абу Нууваса. 
Кружи међу нама вино у златном пехару, Персија га обогати тиковима најразличитијим: / На дну је Хусрев, а на боковима дивле краве, гоне их јахачи, наоружани луком (Gabrijeli 1985: 121).

\section{Напоји ме}

Напоји ме, од јутра ноћ већ поста бела / са две чаше крупноока ирна газела

Са врха прста сабъе од сребра што су / румних јагодииа кана се на них просу

Лепотииа дивна тела свег у свили / у юеним халинама дојка болно иввили

Трбух јој нестао мада не гладује / у витком струку појас што везује

\section{Мржна вина и воде}

Између вина и воде мржне тьттну следе / вино гневом пуиа кад вода га такне /

и у стени чаше очи се виде блесе / нико не нађе лека ту болест да такне.

(Симић прир. 1979: 69)

У песми „Не тугуј над споменима“ он позива оне који јадикују над згариштима и оплакују прошле или неостварене љубави, да се прихвате чаше.

Остави та огњишта напуштена, / Мани се на Салму болних сећања, / У цик зоре прихвати се пића са извора.

Упознај ћерку свемоћне Судбине / Што изабра таму крчага за склониште / Ослобођена свег труња и прљавштине. Вино је попут крви из срца, / Јако је, ако га само окуси усна, / Намршти се од њега лице, а тело стресе.

О испијању рујног вина и опијености лепотом и чарима девојке Абу Нувас говори у песми „Два моја пијанства“.

Не тугуј за тепом Хинд, не плачи ноћима, / Bећ се напиј сред ружичњака / Попут руже вина руменога! 
Кад се вино у твоје очи излије, / Црвенило свога сјаја / Оку и образу тад штедро дарује!

Вино је рубин, а купа бисерја / У руци виткостасе лепотице.

Напаја те вином из ока свога, / Напаја те вином из пехара, / Нема ти спаса од пијанства два!

Уживам у двама пијанствима, / Разликујем се од осталих винопија, / Јер за оно друго знам само ја! (Tanasković prir. 1977: 38-39)

Под крај живота, Абу Нувас се окренуо сасвим другачијој поезији. Да ли се заситио и уморио од разузданог живота, пијанчења и бахијских и епикурејских стихова, или се искрено покајао, тек „стари арапско-персијски Анакреонт (због бриљантног цинизма поредили су га са Хајнеом), завршио је као побожни верник“ и смерни муслиман, пишући покајнице и зухдијате (ap. zuhdiyyāt) - аскетске песме, које се налазе на крају његовог дивана.

Господе, велики су моји грехови и многобројни, али знам да је још већи твој опроштај,

Ако само праведник може да ти се нада, где да грешник онда нађе уточиште?

Дозивам те, Господе, понизно, ко̂ што ти је по вољи. Ако ти одгурнеш моју руку, ко ће да ми се смилује?

Немам ништа чиме бих до тебе стигао, осим наде, и твог узвишеног праштана, и свог муслиманског бића. (Gabrijeli 1985: 122-123)

Бешар Ибн Бурд и Абу Нувас, обојица пореклом Персијанци, утицали су на двојицу великана персијске поезије Омера Хајама (Íakīm 'Umar Hayyām Nīšābūrî; 1048-1131) и Хафиза (Šams al-Dīn Mû̂̂̂amad Íāfî́ al- 
ŠirāÛî; 1325-1390). Омер Хајам је на Истоку био познат пре свега као научник - астроном, математичар и физичар, а бавио се и традиционалним гранама исламске филозофије и теологије. Иза себе је, на пољу егзактних наука, оставио више значајних дела као што су Алгебра (преведена на француски у 1851. и на енглески у Америци 1931. године), радови о специфичној тежини злата и сребра, студије из теоријске и примењене астрономије (радио је у опсерваторијама у Мерву и Исфахану), астрономске таблице и реформисани староперсијски календар, базиран на сличним принципима на којима почива и грегоријански календар (уведен у Европи у 16. веку). Хајамов поетски опус - његове рубаије - постале су прво познате у Европи, преко Фицџералдовог (Edward FitzGerald) слободног препева објављеног 1857. године, а у Персији тек од 1923. године. Рубаију или катрен, кратку и једноставну песничку форму „која од песника захтева мисаоност, концизност и јасноћу изражавања“, Хајам је преузео од ранијих суфијских песника, али је у њу унео новине, усавршио је и обогатио „ширином идеја, смелошћу размишљања и критичким ставом према свету који га окружује“. У рубаијама је изнео своје филозофске ставове и идеје и оне су, слободно се може рећи, „конгломерат епикурејства, скептицизма, песимизма, мистичких и других представа које су циркулисале у оно време међу образованим људима“ (Đukanović 1982a: 162). Рубаије су пуне дубоких мисли и у њима Хајам покушава разумом да докучи загонетку људске егзистенције, тајну овог света, питање судбине, питање фатализма и слободне воље, схватање времена и Божије праксе стварања и уништавања људи, што је метафорички представио поступком грнчара који своје тек створене крчаге разбија без икаквог разлога. 
Омер је рационалист иако сматра (као Лукреције) да је свет пун мана и недостатака, зато је песимист, који увиђа да је тако одувек и брзо постаје ведрији; песник је агностик: за кога је цео свет само сан и илузија и о којем не може ништа сигурно знати ('Ignoramibus'), само што Хајјам ни после тога сазнања не очајава, него проповеда уживање живота (за шта су га мулле осуђивале као и западни схоластичари европске рационалисте), али не епикурејско уживање, него умерени хедонизам у коме се каткада јавља и по која нота горчине, као и код неких великих западних песника. Што је најсимпатичније у овим рубаијама то је демократска црта по којој су сви људи од исте земље-глине, и сви једнаки. [...] Побожно-мистички катрени просто ишчезавају према маси других, можда су просто резултат тадашњег обичаја и моде, а не резултат правог осећања песника - астронома и математичара. (Bajraktarević 1964: 107)

Омер Хајам је сматрао да је циљ живота сам живот и уживање тог живота, а из такве животне филозофије проистекла је слика о њему „као о човјеку хедонисти који заговара уживање на сваком кораку и у сваком тренутку, што је даље представљало Хајјама као присталицу епикурејског учења о сензуалним насладама које су саме себи циљ“ (Džaka 1997: 349-354). Овакву представу о песнику потврђује и чињеница да је вино честа тематика и чест мотив у његовој поезији. Како тумачити Хајамову поезију и да ли се она може сматрати винском питања су око којих се његови интерпретатори највише разилазе. Део „хајамолога“, као што су Руси Жуковски и Смирнов, и Персијанац Фуруги, тумачи његову поезију алегоријски, у суфијском духу сматрајући га песником „који тежи царству вјечног, свијетлог и дивног, гласником топле љубави према Богу“. Кристенсен, Арбери, Розен и још неколицина великих европских оријенталиста Хајама „проглаша- 
вају пјесником хедонизма и пјесником винске поезије. Морочник за Хајјама каже да је 'свјесни богохулник, атеиста и материјалиста', не објашњавајући откуд онда елементи песимизма и скепсе у Хајјамовој поезији“ (Džaka 1997: 354). Угледни сарајевски иранолог Бећир Џака (1937-2008) повезује проблем тумачења Хајамових рубаија са њиховом атрибуцијом, аутентичношћу и бројем, око чега се научници у свету доста споре већ дуже време. Број рубаија које се приписују Хајаму варира од десетак до 1500, а последњих деценија оспорава се и аутентичност најстаријег рукописа који потиче из 1207. године са 252 рубаије и који се чува у библиотеци Кембричког универзитета.

Тематика вина код Хајјама изазива доста контроверзно гледање. У вези са овом тематиком Хајјаму се највише подваљивало и приписивало му се мноштво рубаија које он није спевао. Иначе, у изворним Хајјамовим рубаијама вино се спомиње само у десет рубаија, и то не као главна тема. У тим рубаијама вино се јавља као симбол за угоду и осмислено и корисно провођење живота на овом свијету. [...] Вино као симбол у Хајјамовим рубаијама је посебно средство којим се пјесник служи да би критиковао духовна лица, лажни пуританизам и чуваре јавног морала... [...] У десетак рубаија у којима се спомиње вино, а које су сигурно Хајјамове, види се да пјесниково наводно пијење вина има призвук слободоумља и протеста против лицемјерних теолога који тргују шеријатом и посежу за вакуфском имовином. Поред тога, ако Хајјам каже да пије вино, он истиче како зна да је оно забрањено и да ће за то одговарати, значи он се не хвали кршењем вјерских прописа. (Džaka 1997: 354; 355; 356)

На јужнословенским просторима, од прве половине 20. века јавља се више превода Хајамових катрена; неки су с енглеског, неки с персијског оригинала. Први зна- 
чајнији преводи рубаија с персијског оригинала појавили су у Сарајеву 1920. године - 101 рубаија и 1928. године - 120 рубаија, а преводилац је један од значајних пионира југословенске оријенталистике Сафвет-бег Башагић (1870-1934). Ова два превода обједињена су у издању из 1954. године и у Изабраним дјелима 2 (Caрајево, Свјетлост, 1971; 9-126). Катрене је Башагић тематски груписао на следећа поглавља: „Љубав и вино“ (94 катрена); „Човјек и свијет“ (катрени 95-188) и „Бог и вјера“ (катрени 189-226). Иако рукописна подлога са које је Башагић преводио није много поуздана (сам Башагић је тврдио да његов рукопис потиче из 16. века), Хајама је превео понесено и допадљиво, остваривши при томе, успео превод који оставља одличан утисак, упркос одређеним мањим или већим огрешењима о оригинал. Томе је свакако допринела Башагићева емотивна природа и песнички дар. Преводи Хајамових четворостиха и Хафизових газела спадају међу најуспелије странице његовог преводилачког рада, у којима је на оригиналан и инвентиван начин остварен спој Башагића песника и Башагића оријенталисте. Башагић је превођење доживљавао као креативну и слободну трансформацију једног језичког садржаја у други и као стваралачко домишљање, уз велики преводиочев лични удео и личне интервенције у обликовању стихова на нашем језику. Као илустрацију Башагићевог преводилачког поступка доносимо неколико винских катрена.

1: Збирка поезије и бурение вина, / Комад суха круха - нијема тишина, / а ја и ти сами - око нас пустина. / То је изарство, а не круна од рубина!

3: Без пића и пјесме свијет губи чаре, / а без крчмариие не вриједи паре. / Држећ чашу у руии, о 
рамену плоску / пиј - та то је живот, други не вриједи!

4: Крчмарице, точи вина - та добар је Бог! / Он дијели сваког блага из обила свог. / Не прави се фаризејем, живи док си млад, / ако коме није штета од ужитка твог!

8: Пиј чистога вина из бистра кристала / и сјећај се својих младих идеала! / Вино је крв лозе, а лоза ти збори: / Пиј - не требаш тражити од мене халала!

77: Цвијеће ивате, крчмарице, рујна вина пијмо, / зашто више да клатьмо, и да се молимо? / Прије но што пуста самрт у бусију сједе, да се чама накуцамо, драгих наљубимо!

85: Иако је вино харам, треба знати, коме није, колико се пити може, и с ким човјек да га пије. / Тко услове те испуни, а пити му закон брани, / кажите ми: јӓ тко онда ту благодет пити смије. (Hajjam 1954: 31; 32; 46; 48)

Свакако, најзначајније издање катрена на нашем језику јесте филолошки прецизан, надахнут, стиховани превод 300 рубаија професора Фехима Бајрактаревића (1889-1970), оснивача Катедре зе оријенталистику у Београду (1926). Он је преводио према релевантним кембричким рукописима, из 1207. године са 252 рубаије и из 1259. године са 172 рубаије, а превод је доживео више издања (Beograd, 1964, 1975, 1983, 2017). С обзиром на број преведених катрена, сасвим је разумљиво да сви нису преведени с подједнаким успехом, али „неколико међу њима заслужују место у антологијском избору српске преводне поезије. Још једна одлика даје овом преводу предност пред осталима [...], то је акрибија с којом је рађен, као и поузданост у погледу 
избора и аутентичности“. ${ }^{1}$ Поред превода поменутог корпуса рубаија, Ф. Бајрактаревић је написао и неколико студија о Омеру Хајаму, у којима је обрадио све проблеме значајне за његову личност и поезију, као што су песникова биографија, рад у више научних области, тумачење поезије, атрибуција и број катрена, преводи. ${ }^{2}$ Говорећи о Хајамовој поезији, Бајрактаревић је у својим студијама истакао да је она песнику била нека врста одушка од озбиљног научног рада и у томе га пореди с нашим Руђером Бошковићем. Та поезија је и „израз његове необичне личности, његовог за оно доба дивног слободоумља“, у њој се он подсмева назадној и заосталој средини. У рубаије је Хајам унео свој агностицизам, ударао је „час против судбине и фатализма, час против поретка у свету и самог творца свемира, али је најчешће све то поливао својим 'вином' и зачињавао својим хумором и пародојом“ (Bajraktarević 1965: 25). Корпус од 300 преведених рубаија професор Бајрактаревић је, како је истакао у „Општим напоменама уз Рубаије“, поделио према личном афинитету, по садржини, у четрнаест поглавља. Једно од тих поглавља - треће - носи назив „Вино“ (рубаије 47-101 - стр. 14-22). Из њега издвајамо неколико рубаија.

47: Суние просу зраке на кровове старе, / а шах дана нали вино у пехаре, / вино пиј! мујезин већ на сабах зове: /

1 Иван Шоп, „Фехим Бајрактаревић као компаратиста“. Упоредна истраживања I, Београд, 1976. 68.

2 То су: „Фицџералд и Омер Хајам“, Страни преглед, I, 2, (1927): 101-114; „Један англосаксонски класик персијског порекла“, Летопис Матице српске, 138, 390, 5, (1962): 430-434; „Хајјам код нас“", Анали Филолошког факултета, 3, (1963): 7-22 и „Омер Хајјам - највећи светски песник катрена“. Филолошки преглед, I-II, (1965): 11-31. 
„Ииребу!“ се ори у свет са мунаре.

52: Поспи вином камен: он већ поиграва! / Ко год вино куди, тај је луда права! / Што од мене тражиш да се прођем вина, / кад је то дух који тичност васпитава?!

53: Вечерас ћу бокал вина прибавити, / после друге чаше све ћу оставити: / од разума ћу се и вере развести, / nа са ћерком лозе, свадбу прославити!

98: Паз'те да ми храна буде чаша вина, / ово јантар тиие да је ликрубина! / Када мртав клонем, купајте ме вином, / а сандук ми прав'те од чокота фина!

(Hajjam 1964: 14; 15; 22)

Катрени о вину се појављују и у другим поглављима, на пример у првом насловљеном „Уживање живота“ (рубаије 15-46; стр. 8-13).

31: У дане младости треба вино пити, / с лепим створом треба чисто вино тити; / овај трошни свет је пустина и пустош, / у пустиюи треба пуст и пијан бити!

44: Кажу: биће раја, биће рајских сека, / биће тамо вина, биће меда, млека... / Зато немој бити без вина и драге, / кад на кониу кониа, то те исто чека!

(Hajjam 1964: 10; 12)

Године 2004. код нас се појавила још једна књига са Хајамовим рубаијама, а превеле су их с персијског језика Нада Томић-Драшковић и Жана Јакопџањан. Рубаије у њиховом избору нису тематски разврстане, али имају наслове које су оне дале. О месту и улози вина у Хајамовој поезији у предговору насловљеном „Омар Хајам - песник над песницима“ стоји следеће: „Вино, занесеност њиме - у Хајамовој поезији је чест мотив. Вино је у ствари, песничка метафора суштине живота и неумитне пролазности свега у природи, најпре човека. Како га Хајам схвата - вино је течни рубин, срж по- 
стојања. Води до највишег степена поимања душе - без чега нема људскости“ (Hajam 2004: s. p.).

Ево и једне рубаије с насловом „Шта је рубин“ из ове збирке.

Пехар вина - стотину вера и живота вреди, / Гутььај враниа - иарства кинеског вреди! / Без ружице - чта је рубин на лииу земль: / Горчина - ито хиладу слатких живота вреди! (s. p.)

Хафиз, један од највећих персијских, али и светских песника, рођен је почетком 14. века, у Ширазу, у јужној Персији, који је заједно с Тебризом, на северозападу, у то време био културни и књижевни центар музаферидске Персије. У родном граду, „Персијској Атини“, Хафиз је провео читав свој живот, ту је завршио студије арапског језика и верских дисциплина, ту је потом радио као професор и деловао као мислилац и теолог, ту је писао своје стихове. Хафиз, или како га често називају „Шираски славуј“ оставио је за собом обимно лирско песничко дело - око 700 песама које је постхумно сакупио у диван и објавио његов пријатељ Мухамед Гулендам. Та заоставштина обухвата стотинак рубаија, неколико касида „од којих су на гласу Саки-нама (Пјесма крчмариии) и Мугами-нама (Пјесма пјевачици)“, затим неколико епиграма историјског карактера, неколико краћих месневија у којима је опонашао Низамија, и око 500 газела (Bašagić 1971: 117; Džaka 1997: 399). Мада је Хафизово поетско дело разноврсно, слава му почива на газелима. „Ту је Хафиз ненаткрилив мајстор, како са формалне, тако и са садржинске стране. Његове теме нису нове, то су вечне песничке теме: љубав, вино, лепота, младост, ружа, славуј и друге овима сродне, али их он опева на један нов, само њему својствен начин, 
са новим сликама и бојама, са много финог осећања за природну лепоту, језиком пуним елеганције и грације“ (Bajraktarević 2012: 97). Хафиз је у својој лирици сјединио читаву ранију персијску поетску традицију, али је љубав и вино, који код њега обично иду заједно, опевао на себи својствен начин, особеним језиком без фраза и бомбастичности, са честим играма речи и оригиналним и смелим поређењима, у сликама испеваним са пуно бујне маште и топлих боја, дајући тој синтези чар свог песничког генија и уздижући се од индивидуалног до опште људског, од вечне лепоте и истине, до божанства. У његовим стиховима је истакнуто све оно „што је трајно људско и вечно Божанско, што сачињава смисао живота и суштину света и то на један начин пун олимпијске ведрине и бујне маште, с чаробном снагом у језику и изразу. При томе се он високо уздигао изнад свог доба, отворено износећи своје слободоумно схватање и фино исмејавајући лаж и лицемерство извесних кругова“" (Бајрактаревић 1939: 51).

Тема вина била је присутна у Хафизовој поезији у свим периодима његовог стварања и готово на свим страницама дивана, али је у различитим фазама била различито обојена. На то су утицали и неки његови претходници, пре свих Хајам и Абу Нувас (Arberry 1947: 32-37). Вино се преплиће с другим темама, особито с темом љубави. Исто тако, вино је централно питање у тумачењу Хафизових газела које је почело да се поставља одмах иза његове смрти. Већина Хафизових стихова може се двоструко тумачити - буквално и реално, односно пренесено, мистички и алегоријски. Хафиз је често узимао „еротичне метафоре и изразе из суфијске поезије али има и много места која се апсолутно не могу и не смеју мистично тумачити. [...] На Западу је преовладавало супротно схватање, али с тим да Хафиз 
има мистичних места и да је мистична двосмисленост његових стихова (као код готово свих персијских песника) свесна и намерна, условљена многим фактрима“. Насупрот томе, у Персији и на Истоку, изузимајући Босанца Судија (16. век), доминирало је традиционално алегоријско-мистично схватање Хафизове поезије, које су заступали и неки европски оријенталисти, као што су: де Саси, Таси, Кларк... (Bajraktarević 2012: 97-98). Већина европских иранолога определила за реално и буквално тумачење Хафизове поезије, уз констатацију да је мистична двосмисленост појединих његових стихова била параван за изношење слободоумних схватања, и за критику власти и исмевање лицемерства одређених друштвених кругова, особито суфија. Гете је помирио ове две струје. Он је у Хафизовој поезији налазио и реални и алегоријски смисао. „Шта више, изгледа да се Гетеу нарочито свидела ова намерна двосмисленост, ово стапање реалног и мистичног, ово савладавање чулног и надчулног“, јер је и он у својој поезији од „личног тежио ка општем, од појединачног ка типичном, од видљивог ка симболичном“ (Бајрактаревић 1939: 81). Позивајући се на немачког научника X. Х. Шредера и његову студију Гетеов доживљај Истока (Goethes Erlebnis des Ostens, Leipzig, 1938), Д. Танаковић истиче да „највећа иновација“ у Хафизовој поезији лежи баш у „неразлучивости осетилног/стварног и надосетилног/духовног, што тематско-садржински почива на спојевима традиционално неспојивих песничких мотива, али у бити значи један виши, заправо категоријално највиши степен слободоумног промишљања света и човековог места у њему. То је вредност коју је код Хафиза препознао Гете, доживевши га као 'брата близанца" (Tanasković 2003: 48). Анемари Шимел (А. Schimmel), стручњак за суфизам, сматрала је да у тумачењу Хафизове поезије не може бити искључивости. 
Заговорници чисто мистичког значења Хафизових газела једнако су се ватрено залагали за своје ставове као и они који су у његовој поезији налазили искључиво сензуалну љубав, земаљску опијеност 'ћерком лозе' и прави хедонизам. Па ипак оба тврђења су подједнако удаљена од истине. [...] Изгледа стога бесмислено трагати било за чисто мистичком, било, пак, за чисто профаном интерпретацијом песама Хафиза, Џамија или Иракија - њихова двосмисленост је намерна, колебање између два нивоа бића се свесно одражава [...], а склоп и прелив значења једне речи може се у сваком тренутку променити, умногоме као што се у персијској џамији према добу дана дубински мења боја украсне мајолике. (2011: 202)

При свему томе, треба нагласити да је много је више Хафизових стихова у којима се реч вино јавља у конкретном значењу, а у неким газелима, на пример у четрдесетом, сам песник је изричит у томе да пева о правом вину.

Хвала Богу кад су врата крчме отворена, / јер ја имам потребу за тим вратима,

Сви пехари од пијанства су узаврели, / а то вино што је тамо истина је, а не алагорија. (Džaka 1997: 413)

У газелима из младости насталим у првим фазама стваралаштва Хафиз говори о телесној љубави и страсти, а вино је конкретно пиће, које песнику пружа утеху, лечи љубавне јаде и помаже да следи своје срце (Džaka 1997: 403-404). И у зрелијим годинама, Хафиз се занимао за овоземаљске ужитке, а у његовим винским песмама доминирају хедонистичке црте, као у газелу 101.

Што је то скривено вино и живот, то је нешто без основе, / ја се сврстах у ред боема па нека буде шта ће бити. (Džaka 1997: 405) 
Вино није Хафизу лек само за срце, већ и за разум. Немоћан да одгонетне загонетку живота, одаје се пићу и окреће се вину.

Причај о вину и певачу / Остави другоме светске тајне. Јер нико не може мудрошћу / Решити те проблеме вајне. (Bajraktarević 2012: 171)

У неким периодима Хафизовог живота, када је окрутна власт спроводила строге шеријатске прописе и затварала механе (перс. mejhane), он се окреће суфизму и позива на опрез при конзумирању вина.

41: Иако вино даје весеље, а повјетараи, расипа ивијеће, / не пиј вино уз харбу јер мухтесиб је строг.

Ако ти западне пехар вина и добар друг, / пиј паметно, јер вријеме је смутьиво.

Сакриј чашу у рукав хрке своје, / јер вријеме ово крв лије као пехар вино.

202: О Боже, не одобри то што су врата крчми затворили, / да би отворили врата претвараға и личемјерства. (Džaka 1997: 405)

У својим газелима Хафиз је тада, на увијен и скривен начин, исказивао протест против тираније и девијација у друштву, критиковао лажни морал представника власти и верских кругова и протурао идеје о духовним слободама човека.

Сигурно је да се у Хафизовој поезији налазе многе алузије на догађаје и идеологије тог времена. Из различитих мотива Хафиз се при томе служи симболиком суфизма и прибегава вишеслојном исказивању својих мисли. [...] Свако покољење налазило је код Хафиза оно што му је одговарало: стари и побожни суфија своје, заљубљени младић своје, па чак ортодоксно и увјек подозриво свештенство прихватило је Хафиза и почело га представљати 
као тумача ортодоксног ислама. [...] У вјерским круговима и медресама Хафизови стихови су, дакле, интерпретирани као симболичко излагање основа и традиције исламске вјере и ортодоксног суфизма. На другој страни, обесправљени и слободоумнији читаоци прихватили су и тумачили Хафизову поезију као медиј кроз који се исказују њихове туге и радости. Односно, као израз слободоумља. Они су у Хафизовим стиховима тражили и налазили критику свега онога што не ваља, као на пример критику султанове суровости и самовоље, па макар се у стиховима критиковани звао и сурова султан льепотица, те критику лицемјерства и обмана од стране свештенства. (Džaka 1997: 402)

Суфијска фаза није дуго трајала код песника. Спознавши шарлатанство и заосталост суфија, он се у својим стиховима окомљује на њих и још страсније заговара хедонизам уз вино, песму и драгану.

424: Суфијо дођи, јер чаша је као тала пуна вина, / Зар да слушаш бесмислище и гомиле неистина? [...]

Вина точи, да јој драж посве разоткрије, / Најлепша је тьублена моја кад се пије!

Ветар саба каже да уживамо у младости; / Де, младићу, винце точи пијмо у радости!

491: Драга рече: „О Хафизе на пташт вино кану; / зар је могуће, дервишка реда се ману!“ (Хафиз 2015: 447; 518)

351: Не дао Бог да у вријеме ружа оставим вино, / ја који се оглашавам памећу, зар бих тако нешто могао направити.

Гдје је свирач да све што је плод аскезе и знана, / жртвујем звуку харфе, бербета и наја.

Збрка ријечи у медреси у бриге ме сада баиа. / Неко вријеме посветићу својој драгој и вину. (Džaka 1997: 407)

Може се слободно рећи да је Хафиз временом изграђивао и мењао своје схватање љубави и однос према 
вину. Тек у последњем периоду Хафиз прихвата поетски суфизам ранијих суфијских песника Атара († са 1220) и Румија (1207-1273), на основу чега изграђује сопствени мистички систем сматрајући да сав свет произлази од Вољеног и Апсолутне лепоте, а да љубав омогућује човеку да оствари прочишћење и достигне друштвено савршенство. „Љубав омогућава човјеку да се уздигне изнад пролазног опстанка и да као кап воде нестане у мору вјечности, тј. помоћу љубави се може стићи до Вољеног и видјети Његова љепота“ (Džaka 1997: 409). Значајна улога у томе припада вину, које сада има симболично и апстрактно значење, које је морални покретач и које у том контексту постаје средство за духовно прочишћење и приближавање вољеном.

Функција вина у суфијској поезији друкчија је од оне коју је оно имало у поезији предисламских народа или несуфијских пјесника. Вино у суфизму симболизира опојно средство које ће помоћи заљубљеном (у Њега) да доживи (божанско) пијанство и да допре до Њега. Метафором вино пјесници инсистирају на ирационалном карактеру њиховог искуства, одричући се интелекта који, по ријечима Бомбачија, представља препреку свевишњој форми гностичке спознаје и религијског живота. (Šamić 2014: 93)

Суфијски системи, па и поетски суфизам, саткани су од низа симболичких апстракција, алагорија и метафоричких слика. Вино, крчма, свећа, лептирица, лепотан, лепотица, непроходне шуме, идол, око, усне, увојци срце, лице, рад, пехар, пријатељ (перс. dost), прашњава земља, вода... само су неки од честих суфијских термина и кључних речи који у поезији имају специфична значења. На пример: „крчмар“, „пехарник“ или „напијач“ (перс. sāki) је сам бог који душе напаја 
божанским вином, а лептирица која кружи око пламена свеће све док на њему не изгори, заправо је чежња душе за божанском светлошћу (Брагински 2011: 194; Бертељс 2011: 211; Tamimdari 2004: 128; Bajraktarević 2012: 65).

Суфијски приступ и суфијска реторика у поетском стваралаштву јавља се у исламском свету, у 10. веку, дајући поетској речи и поетском изразу нове квалитете. У том контексту треба поменути да је и код Арапа било мистичних песника, а најпознатији међу њима је Египћанин Омара Ибн ел Фарида ('Umar Ibn al-Fāriã; $\dagger 1235)$. У његовом дивану посебно место заузима винска песма Хамрија, као и 'велика Таија' (поема с римом на т) од 760 стихова, у којима је речником винске и љубавне поезије изразио божанску љубав и опијеност суфија, у којима се мистични смисао „јасно провиди испод дионизијско-љубавног вела“, које су значењски вишеслојне и могу се тумачити буквално и реалистички, односно метафорички и мистички (Gabrijeli 1985: 141). Код нас је преведена песма „Мистично вино“, из које издвајамо неколико стихова.

У спомен Вотеног бића вина смо пили / И опили се пре него ито су створени виногради.

Пун месеи му је пехар, а оно је попут суниа, / Виторог срп га унаоколо налива, / Ако се измеша, колико само звезда заблиста!

Да не би юеговог опојног мочусног мириса / До крчме где се оно точи не бих стигао никада, / Да није тог његовог бъеска и сјаја, / Описати га не би могли надахнуће и пое3uja. (Tanasković prir. 1977: 66)

Персија је била изузетно погодно тло за цветање суфијске поезије која заузима врло значајно место у целокупном персијском поетском наслеђу, а суфијски 
елементи и реторика су присутни код великог броја персијских песника.

Персијска лирика без суфијских теорија никада не би стекла свој особити шарм; оне су позадина на којој се ова поезија развија, а тензија између световног и религијског тумачења живота разрешава се у песмама истакнутих мајстора ове уметности кроз савршен склад духовних, песничких и сензуалних компонената. Суочен са врхунском лепотом у својим љубавним сазнањима, песник је умевао да створи уметничка дела која тај величанствени сјај одражавају у малим, светлим, призматичним фрагментима, а ови узети заједно, могу бити у стању да створе представу о изворном бљеску узвишене лепоте. (Шимел 2011: 203)

Део те лепоте представићемо кроз још неколико Хафизових стихова у преводу Сафвет-бега Башагића, Фехима Бајрактаревића и Бећира Џаке. Из касиде насловљене „Саки наме“ („Пјесма крчмарици“), посвећене шаху Мансуру изабрали смо неколико дистиха и здравицу са њеног краја.

2 Крчмарице вина амо, алкемијом што га зову, / Јер с Нуховим жићем даје и благајну Карунову. [...]

4 Крчмарице, наточи ми ону искру огюа жива / Коју негда Заратустра испод земле истражива.

5 Понеси ми, јер бекрије не гледају на идоле: / Да л’се туди арној земли, или жаркој ватри моле.

6 Крчмарице, амо вина, с ког Џемова чаша слови / да се кроз юу види свијет невиђени и духовни.

8 Крчмарице, дај ми чашу штоно из юе Џемшид пије, / Што никада није празна, ито се сама вином лије. [...]

3 Џем или Џемшид је персијски владар из династије Пишдадијан, који је, по легенди, заслужан што се грожђе које је добио на поклон претворило стајањем у „отров“ - чаробни лозов сок који га је овековечио у оријенталној поезији. 
11 Крчмарице, дај ми вина, тешке бриге што изгара, / Штоно таву накресану кроз планину пут отвара. [...] 18 Дај ми вина да се чистим од гријеха и од мана, / Нека ме се једном прође мисо давна помрчана.

19 Гледај како рујно вино моје срие разиграва, / Гледај како у пијанству открива се мудрост права. [...]

Дижем ову чашу вина, с којом своју душу гријем, / Што му желим, то му велим: $у$ здравлье ти Шаху пијем.

Ходи, побожна душо, моја је чаша чиста, / Да ви'ш како се вино ко чисти рубин блиста. (Bašagić 1971: 222-224)

Део песме „Певај, појче“ преносимо у Бајрактаревићевом преводу.

Певај, појче милог гласа, / Певај опет, сваког часа! / Тражи вино, разбибригу, / Тражи опет, пусти бригу [...]

Ао, саки белих ногу, / Ја сам пијан још пит' могу: / Пуни пехар, брзо амо, / Пуни опет, точи само!

Шта имадеш од свог жића / Кад се стално клониш пића? / Напиј драгој чашу вина, / Напиј опет тог рубина! Друг једини који данас / Реч не крии и начела, / То је крчаг чистог вина / И книжииа од газела. [...]

Збаии везе и об'везе, / Стаза спаса све је краћа: / Чашу зграби, јер се више / Кратки живот не повраћа!

Никад нећеш наћи да је / Хабиз жртва трезвености: / E би рек'о да је пијан / Пијућ' вино вечитости. (Bajraktarević 2012: 165-166)

Године 2015. Културни центар Исламске Републике Ирана издао је Хафизов Диван, у коме је Бећир Џака превео на наш језик 492 газела (стр. 1-519), једну месневију - Дивла газела (стр. 520-523), и две касиде - Сакинама (стр. 524-526) и Песма о свирачу (стр. 527-528). Уз превод дат је и персијски оригинал песама, као и опширна објашњења, из пера Махмуда Шалујија (стр. 530-574). Лепоти овог издања доприноси изванредна ликовна опрема књиге, која укључује више минијатура 
и неколико страница рукописа дивана из 1654. и 1659. године. Из овог издања изабрали смо дистихе из неколико газела и касиде Сакинама.

1: О крчмару, наздрави льудма чашом, и ти; / Испрва льубав бје лака, сад тешкоћа је круни. [...]

Пир магова учи да се вином простирка залије, / Јер су у обичаје прихватана упућени сјајно;

96: Јуче ме поучи винар, Боже буди добар с ниме; / „Попиј вина да изгнаш из сриа мисли худе“;

Рекох да бих због виниза изгубио и част и име, / А, он рече: Послушај мене, па шта буде!"

127: Гностик се чистим вином уми, у зоре иик / Па, чист механи крену, вино где се служи!

За облаком скри се купе суниа златолик; / Бајрам млађак нареди: „Пехар нек кружи!“ [...]

Буде ти скуп рад молитве имама свог чек'о, / Реци Хафизе, нек' не чека: вино већ га опра!

\section{Сакинама}

[...]

Тог вина што иарство нуди, крчмару наточи, / нек ми чистоту негову срие посведочи!

Дај, крчмару вина, можда очисти мене; / па се са осмехом вратим из земъе понижене!

У рају с анђелима место ми је спремно; / што сам онда ичим везан за то тело земно!

Погледај лиие среће, крчмару ито вина дајеш; / убиј ме рујним вином, па види мудрост шта је!

Ја сам онај који у винске чаше стаклу / све ствари света види к'о у огледалу какву.

Ја међ' пијанцима о побожности зборим, / о кральевству причам са сиромаштвом својим.

У пијанству могуће је бисер тајни пробушити; / у незнағу не можеш своју тајну крити!

Пијан Хабиз песму своју пева сад небесима; / Венера му лиром својом, гле, узвраћа поздравима! (Хафиз 2015: 526) 


\section{Извори и литература}

Arberry, Arthur (ed.). Fifty Poems of Íáfî. Tehran: Padideh, 1947. Štampano.

Bajraktarević, Fehim. „Život i delo Omera Hajjama“. Omer

Hajjam. Rubaije. S persijskog preveo i napomene napisao dr

Fehim Bajraktarević. Beograd: „Rad“, 1964, 102-108. („Reč i

misao", kolo VI; knj. 143). Štampano.

Bajraktarević, Fehim. „Omer Hajjam - najveći svetski pesnik

katrena“. Filološki regled I-II (1965): 11-31. Štampano.

Bajraktarević, Fehim. Iz persijske književnosti. Beograd: Utopia,

2012. Štampano.

Бајрактаревић, Фехим. „Утицај Истока на Гетеа“ / Гласник

Николе Чупића XLVIII, (1939): 1-132. Штампано.

Bašagić, Safvet-beg. „Hafiz“. Safvet-beg Bašagić. Izabrana djela 2.

Sarajevo: Svjetlost, 1971. 208-226. Štampano.

Бертељс, J. Е. „Белешке о песничкој терминологији персијских

суфија“. Дарко Танасковић и Иван Шоп (прир.). Суфизам.

Београд: Хришћанска мисао, 2011, 208-213. Штампано.

Брагински, И. С. „Власт срца“. Дарко Танасковић и Иван

Шоп (прир.). Суфизам. Београд: Хришћанска мисао,

2011. 194-200. Штампано.

Gabrijeli, Francesko. Istorija arapske književnosti. Sarajevo:

Svjetlost, 1985. Štampano.

Gibb, H. A. R. Arabic Literature. Oxford: University Press, 1974. Štampano.

Grozdanić, Sulejman. Stara arapska poezija. Sarajevo: Svjetlost, 1971. Štampano.

Đlizarević-Simić, Ajša. „Arapska književnost 'abasidskog perioda“. Mogućnosti 8-9 (1979): 926-942. Štampano.

Đukanović, Marija. „Arapska književnost“. Povijest svetske književnosti. Zagreb: Mladost, 1982. 99-127. Štampano.

Đukanović, Marija. „Persijska književnost“. Povijest svetske književnosti. Zagreb: Mladost, 1982a. 153-185. Štampano.

Kovač, Mirko. „Vino u književnosti“. Feral Tribune, 03. 11. 2001. Veb. 7. 11. 2018.

Крачковский, Игнатий Юлианович. „Сасанидская чаша в стихах Абу НувА́са“. Избранные сочиненияа. Москва·Ле- 
нинград: Издательство Акадетии Наук СССР, 1956. 336354. Штатпано.

Nicholson. R. A. A Literary History of the Arabs. Cambridge: University Press, 1969. Štampano.

Simić, Vojislav. „Arapska književnost predislamskog perioda“. Mogućnosti 8-9 (1979): 853-876. Štampano.

Simić, Vojislav. „Arapska književnost 'umejjadskog perioda“. Mogućnosti 8-9 (1979): 891-925. Štampano.

Симић, Војислав. „Омер Ибн Аби Рабиа“. Филолошки преглед 1-4 (1971): 31-54. Штампано.

Симић, Војислав (прир.). Класична арапска поезија (VI-XVII век). Избор, превод, текстови и белешке Војислав Симић. Крушевац: Багдала, 1979.

Smailagić, Nerkez. Leksikon islama. Sarajevo: Svjetlost, 1990.

Šamić, Jasna. Mistika i mistika. Sarajevo; Zagreb: Baybook, 2014. Štampano.

Šebel, Malik. Rečnik zaljubljenika u islam. Beograd: Službeni glasnik, 2017. Štampano.

Tamimdari, Ahmed. Istorija persijske književnosti. Beograd: Kulturni centar Islamske Republike Irana: Društvo srpskocrnogorskog prijateljstva, 2004. Štampano.

Tanasković, Darko (prir.). Arapsaka poezija. Beograd: Rad, 1977. Štampano.

Tanasković, Darko. „Hafiz i Gete: kongenijalno pesničko sazvučje“. Anđelka Mitrović (prir.). Hafiz i Gete. Beograd: Kulturni centar Islamske Republike Irana, 2003. 44-51. Štampano.

Tanasković, Darko. „Najautentičnija arapska umetnost“ / Arapska poezija. Izbor Darko Tanasković. Beograd: Rad, 1977. 129138. Štampano.

Hajam, Omar. Rubaije. Prevod Nada Tomić-Drašković i Žana Jakopdžanjan. Beograd: Društvo srpskocrnogorsko-iranskog prijateljstva, 2004. Štampano.

Hajjam, Omer. Rubaije. S persijskog preveo i napomene napisao dr Fehim Bajraktarević. Beograd: „Rad“, 1964. („Reč i misao“, kolo VI; knj. 143). Štampano.

Hajjam, Omer. Rubaije. S persijskog preveo Mirza Safet. Zagreb: Mladost, 1954. Štampano. 
Хамваш, Бела. Филозофија вина. Београд: Драслар партнер, 2011. Штампано.

Хафиз Ширази. Диван. Превод Бећир Џака. Београд: Културни центар Исламске Републике Ирана, 2015. Штампано.

Hiti, Filip. Istorija Arapa. Sarajevo: Veselin Masleša, 1983. Štampano.

Džaka, Bećir. Historija perzijske književnosti: od nastanka do kraja 15. vijeka. Sarajevo: Naučnoistraživački institut „Ibn Sina“, 1997. Štampano.

Шимел, Анемари. „Ружа и славуј: персијска и турска мистична поезија“. Дарко Танасковић и Иван Шоп (прир.). Суфизам. Београд: Хришћанска мисао, 2011. 201-207. Штампано.

Andjelka Mitrovic

\section{WINE IN THE ORIENTAL POETRY}

Both wine and toast poems have been present in the literature of the ancient people of the Middle East, as per example in the literature of the Ancient Egypt of the period of the New Kingdome (1600-1100). However, they have not been present in all oriental poetic traditions in the same measure and in the same way. For this paper, we would elaborate the topic of wine in the Arabic and Persian poetry. Poetry is beyond any doubt the most authentic and most popular branch of art among the Arabs. The beginning of the Arabic poetry could be traced among the numerous tribes that had roamed the desert areas, steppes and oasis of the Arabian Peninsula in the $5^{\text {th }}$ and $6^{\text {th }}$ century. Its main topic had been the wholesome picture of their life, influenced by the authentic Arabic spirit and way of thinking. The basic form of this poetry has been called qasida, "a song with the purpose", with the strict thematic opus, restricted on the descriptions of nature, the desert in the first place, on the description of the tribal wars and love. That strict poetic complex had become and remained the poetic canon of the Arabic poetry, imitated by all later poets, 
who had not added anything new to it. The true modernization of the Arabic poetry had occurred, both formally and thematically, in the "Golden Century" during the rule of the Abbasid dynasty (750-1258). The significant contribution had been given by the representatives of the subjugated nations, especially the Persians. Among the poets of this period, by the originality of the poetic pictures, as well as by freshness of their ideas, two poets could be singled out. Those poets, both Persians by origin, Bashar Ibn Burd (714-783) and Abu Nuwas (756-814), had introduced in their verses, beside other things, the songs, music, toasts and wine. Their influence is immense and could be felt in the poetry of the grand poets of Persian, but general literature as well, Omer Khayyam (1048-1131) and Hafiz (1325-1390), in whose poetry the eternal poetic topics such as love, beauty, youth, rose, wine and the others, had been presented in the new, original way characteristic for those geniuses of poetry. Their poetry, especially on the topic of pouring and drinking wine, which is forbidden by Islam, give possibility to the double interpretations - literal, i.e. realistic one, as well as the allegoric and mystic one. 